\title{
ポーラスアルミニウムの異方性発泡挙動の定量的評価
}

\author{
鈴木良祐* 北薗幸一 \\ 首都大学東京大学院システムデザイン研究科 \\ J. Japan Inst. Metals, Vol. 74, No. 5 (2010), pp. 314-320 \\ (C) 2010 The Japan Institute of Metals
}

\section{Quantitative Evaluation of the Anisotropic Foaming Behavior for Aluminum Foams}

\author{
Ryosuke Suzuki* and Koichi Kitazono \\ Graduate School of System Design, Tokyo Metropolitan University, Tokyo 191-0065
}

\begin{abstract}
The anisotropic foaming behavior of the aluminum precursor manufactured by powder metallurgical process was investigated quantitatively. The precursor was manufactured using the uniaxial hot pressing and compressed parallel and perpendicular to hot pressing direction at room temperature. Foaming tests were carried out using the cubic specimen cut from the precursor. In order to evaluate expansion anisotropy, the deviatoric strain tensor was defined using the expansion strain tensor. The absolute values of three diagonal components of deviatoric strain tensor increase with increasing the prestrain. The anisotropic pore shape was also evaluated using the mean pore aspect ratio and the pore orientation. It is found that the prestrain plays an important role during the foaming of the precursor.
\end{abstract}

(Received January 6, 2010; Accepted February 1, 2010)

Keywords: aluminum foam, powder metallurgy, foaming behavior, anisotropy, image analysis

\section{1. 緒言}

内部に多数の気孔を内包するポーラス金属は軽量, 吸 音1)，断熱2)などのユニークな特性を有している．特に，軽 量かつ高剛性なポーラスアルミニウムは, 環境保全意識の高 まりから, 自動車, 航空, 船舶などの輸送機器アプリケーシ ヨンに関して, 軽量構造材料として注目されている.これま でに, ポーラスアルミニウムの作製方法はいくつか提案され ている3,4). 一般的に大型のポーラスアルミニウムを安価に 作製できる溶湯発泡法と near net-shape 成形が可能なプリ カーサ法が広く用いられている．前者は溶融したアルミニウ ム中に, 不活性ガスを導入するまたは, 発泡剂粉末を添加す ることで発泡体を得る方法である. 後者はアルミニウム中に 発泡剂粒子を分散させたプリカーサを発泡剂の分解温度以上 に加熱することで発泡体を得る方法である. プリカーサの作 製法として，一般的に粉末法が用いられている. 粉末法では アルミニウム粉末と発泡剂粉末を混合し, ホットプレス, 押 出し, 圧延などを利用して固化することでプリカーサを得 る. 合金粉末を利用することで機械的特性に優れたポーラス アルミニウム合金を得ることができるが，合金粉末が高価で ある.プリカーサを安価に作製するために，バルク材を出発 材料としたプロセス ${ }^{2)}$ や切削チップの再利用5)についても検 討されている.

溶湯発泡法を用いてポーラスアルミニウムを作製する場

\footnotetext{
* 首都大学東京大学院生 (Graduate Student, Tokyo Metropolitan
} University)
合, 気孔形状は等方的(球形)となる. プリカーサ法の場合, 発泡挙動は発泡条件 (加熱温度6,7), 加熱保持時間 ${ }^{6-9)}$, 昇温 速度 ${ }^{6,10)}$, 雾囲気圧力 $\left.{ }^{7,9)}\right)$ だけではなく, 加工履歴に依存す ることが経験的に知られている. 例えば, 押出し加工された プリカーサは押出し方向と垂直に優先的に膨張する11,12). 液 相中に気孔が生成されるなら, 重力効果を無視すれば, 発泡 挙動は等方的になる. プリカーサ法では, プリカーサをアル ミニウムの融点以上に加熱する場合でも, 昇温中の固相状態 で気孔が生成され始める。これは，ポーラスアルミニウムの 作製に発泡剂として広く用いられている水素化チタン $\left(\mathrm{TiH}_{2}\right)$ の分解温度 (約 $\left.770 \mathrm{~K}^{10)}\right)$ が, アルミニウムの融点に 近いためである. 結果として, プリカーサ法を用いる場合, 異方的な気孔形状を有する発泡体を得る. 気孔形状の異方性 に起因して, 発泡体の機械的性質13-15) や熱的性質2,15,16) が異 方的になることがモデル計算や実験により明らかにされてい る.これらは, プリカーサの加工履歴により発泡体の特性が 変化する可能性を示している. しかしながら, 発泡挙動にお よぼす発泡条件の影響に関する報告は多いが，プリカーサの 加工履歴と発泡挙動の関係について定量的に議論した報告は ない. 発泡体の機械的性質や熱的性質の制御および発泡挙動 の理解を深めるために, これらの影響を調べることは有益で ある. 本研究では, 特に発泡挙動異方性 (膨張方向と気孔形 状におよぼす加工履歴の影響を調べるため, プリカーサに 予ひずみを与え, 予ひずみが発泡挙動異方性に与える影響に ついて定量的に評価する。また，発泡挙動異方性におよぼす 加熱保持時間の影響も定量的に議論する. 


\section{2. 実 験 方 法}

\section{1 プリカーサの作製}

アルミニウム合金粉末を5083 アルミニウム合金板から削 りだし，ボールミルを用いて粒径 $300 \mu \mathrm{m}$ 以下に粉砕した. アルミニウム合金粉末に 1 mass \%の $\mathrm{TiH}_{2}$ 粉末 (粒子径 45 $\mu \mathrm{m}$ 以下) を加えた混合粉末を内径 $30 \mathrm{~mm}$ の円筒形金型に入 れ, $753 \mathrm{~K}, 50 \mathrm{MPa}, 60 \mathrm{~min}$ の条件で一軸ホットプレスを行 い，円柱状プリカーサを作製した．ここで，ホットプレス方 向を $x$ 軸と定義した (Fig. 1).

プリカーサから直方体 $\left(L \times L \times L_{0} \mathrm{~mm}^{3}, L_{0} \geq L\right)$ を切り出 した．ここで， $L=10 \mathrm{~mm}$ であり， $L_{0}$ は $x$ 軸に平行または 垂直である. 直方体を室温において $L_{0}$ から $L$ まで圧縮する ことで以下の式で定義される予ひずみ $\varepsilon_{/ /}^{\mathrm{PS}}\left(L_{0}\right.$ が $x$ 軸と平行 $)$, $\varepsilon_{\perp}^{\mathrm{PS}}\left(L_{0}\right.$ が $x$ 軸と垂直 $)$ を与えた.

$$
\varepsilon_{/ /}^{\mathrm{PS}}=\varepsilon_{\perp}^{\mathrm{PS}}=\frac{L-L_{0}}{L_{0}}
$$

予ひずみを与えて変形した試験片から一辺 $10 \mathrm{~mm}$ の立方体 試験片を切り出し, 発泡試験に用いた.

\section{2 発泡試験}

最初に, プリカーサの発泡挙動異方性におよぼす加熱保持 時間の影響を調べた．立方体試験片を $\mathrm{BN}$ 粉末を塗布した鋼 板に設置して約 $580 \mathrm{~K}$ に予熱し，鋼板ごと $1073 \mathrm{~K}$ に加熱さ れた電気炉の中心に挿入した. 加熱保持時間 $t_{\mathrm{H}}=0 \sim 900 \mathrm{~s}$ 経過後, 炉内より取り出した試験片を室温で冷却した。ここ で，発泡試験中の重力方向を $z$ 軸と定義した (Fig. 1). 試験 片温度をリファレンスブロックに取り付けた熱電対を用いて 測定した．次に，発泡挙動異方性におよぼす予ひずみの影響 を調べるために，立方体試験片 $\left(\varepsilon_{/ /}^{\mathrm{PS}}, \varepsilon_{\perp}^{\mathrm{PS}}=0 \sim 0.34\right)$ を用いて 加熱保持時間 $t_{\mathrm{H}}=300 \mathrm{~s}$ の発泡試験を行った.

発泡試験後, 試験片密度 $\rho^{*}$ *アルキメデス法を用いて測 定し, 式 $(2)$ より気孔率 $p$ を算出した.

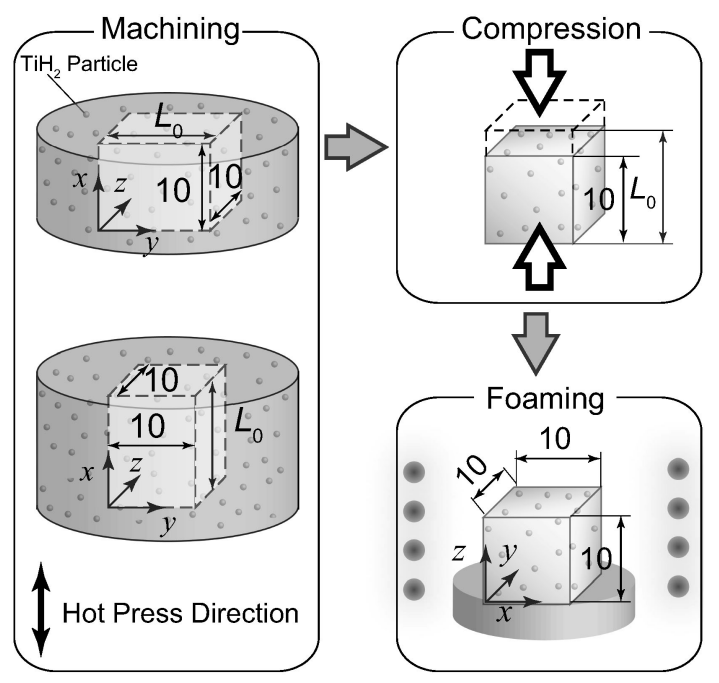

Fig. 1 Schematic illustration of the setting direction of the specimen in each experimental process.

$$
p=\left(1-\frac{\rho^{*}}{\rho_{\mathrm{s}}}\right)
$$

ここで， $\rho_{\mathrm{s}}$ は 5083 アルミニウム合金緻密体の密度 $(2.67$ $\mathrm{Mg} / \mathrm{m}^{3}$ )である.

膨張方向異方性を定量的に議論するために, $x, y, z$ 軸に平 行方向の最大寸法 $L_{x}, L_{y}, L_{z}$ をノギスで測定し, 最大膨張ひ ずみを以下のように定義した。

$$
\begin{aligned}
& \varepsilon=\left(\begin{array}{lll}
\varepsilon_{x} & 0 & 0 \\
0 & \varepsilon_{y} & 0 \\
0 & 0 & \varepsilon_{z}
\end{array}\right) \\
& \varepsilon_{x}=\frac{L_{x}-L}{L} \\
& \varepsilon_{y}=\frac{L_{y}-L}{L} \\
& \varepsilon_{z}=\frac{L_{z}-L}{L}
\end{aligned}
$$

発泡過程における形状変化と体積変化を分けて考えるため に，以下の式で定義される偏差ひずみを用いた。

$$
\begin{aligned}
& \varepsilon^{\prime}=\left(\begin{array}{ccc}
\varepsilon_{x}^{\prime} & 0 & 0 \\
0 & \varepsilon_{y}^{\prime} & 0 \\
0 & 0 & \varepsilon_{z}^{\prime}
\end{array}\right) \\
& \varepsilon_{x}^{\prime}=\varepsilon_{x}-\frac{1}{3} \varepsilon^{\mathrm{V}} \\
& \varepsilon_{y}^{\prime}=\varepsilon_{y}-\frac{1}{3} \varepsilon^{\mathrm{V}} \\
& \varepsilon_{z}^{\prime}=\varepsilon_{z}-\frac{1}{3} \varepsilon^{\mathrm{V}}
\end{aligned}
$$

ここで， $\varepsilon^{\mathrm{V}}$ は体積ひずみであり最大膨張ひずみの対角成分 を用いて，次式で表される。

$$
\varepsilon^{\mathrm{V}}=\varepsilon_{x}+\varepsilon_{y}+\varepsilon_{z}
$$

等方的に発泡する場合，最大膨張ひずみの対角成分は全て等 しいので,

$$
\varepsilon_{x}^{\prime}=\varepsilon_{y}^{\prime}=\varepsilon_{z}^{\prime}=0
$$

となる・

発泡体の概観を $z$ 軸方向から観察した後, 発泡体を $z$ 軸に 垂直に切断し, $x-y$ 断面の観察を行った. 断面を耐水研磨紙 を用いて１200 まで研磨した後, セル壁と気孔部に黒鉛粉 末を塗布し，セル壁の黒鉛粉末を＃1200の研磨紙を用いて 除去することで気孔とセル壁の濃淡を際立たせた. 表面処理 した断面をデジタルカメラを用いて撮影した。気孔形状異方 性を定量的に評価するために, 画像解析ソフト Image J (ver. 1.42q) を用い, 平均気孔径 $d_{\mathrm{m}}$, 平均気孔アスペクト比 $\alpha$ と気孔の配向 $\theta$ を測定した。このとき， $0.02 \mathrm{~mm}^{2}$ 以下の 微細な気孔は測定から除外した. 平均気孔径は, 面積相当円 直径とした. 平均気孔アスペクト比は気孔形状を楕円に近似 したときの短径 $d_{2}$ を長径 $d_{1}$ で除した值として定義し, 気孔 の配向は長径と $x$ 軸とのなす角度 $\theta\left(0 \leq \theta \leq 180^{\circ}\right)$ を用いて評 価した (Fig. 2)。 $\theta$ が $0^{\circ}$ または $180^{\circ}$ に近い場合, 気孔の長径 は $x$ 軸方向近傍に配向し, $\theta$ が $90^{\circ}$ に近い場合, 気孔の長径 は $y$ 軸方向近傍に配向する. 


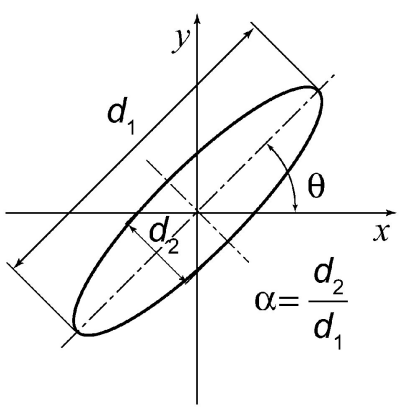

Fig. 2 Schematic illustration of the pore orientation.
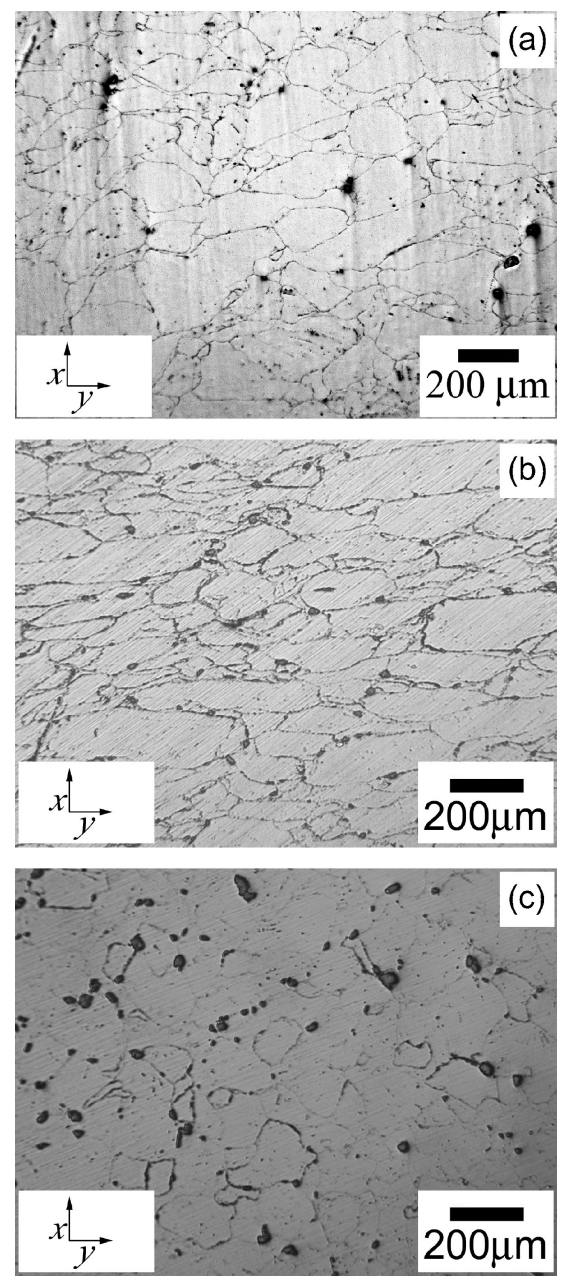

Fig. 3 Optical micrographs of the cross section area of the precursors (a) without prestrain, with prestrain (b) $\varepsilon_{/ /}^{\mathrm{PS}}=$ -0.34 and $(\mathrm{c}) \varepsilon_{\perp}^{\mathrm{PS}}=-0.14$.

\section{3. 結果および考察}

\section{1 プリカーサ}

試験片 $x-y$ 断面を光学顕微鏡で観察した結果を Fig. 3 に 示す．予ひずみを与えなかった試験片の相対密度は $99 \%$ 以 上であったが，素材である合金粉末同士の接合界面が観察さ れた。予ひずみを与えた試験片においてクラックが確認され た。

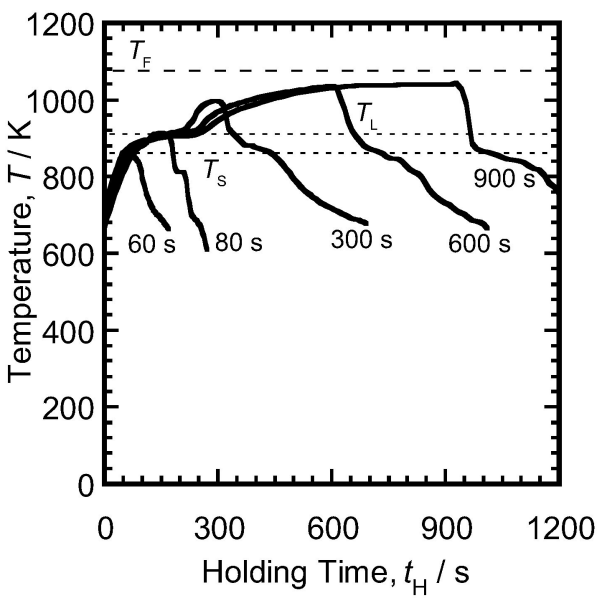

Fig. 4 The temperature profile of the specimens during the foaming test. $T_{\mathrm{S}}$ : solidus temperature. $T_{\mathrm{L}}$ : liquidus temperature. $T_{\mathrm{F}}$ : furnace temperature.

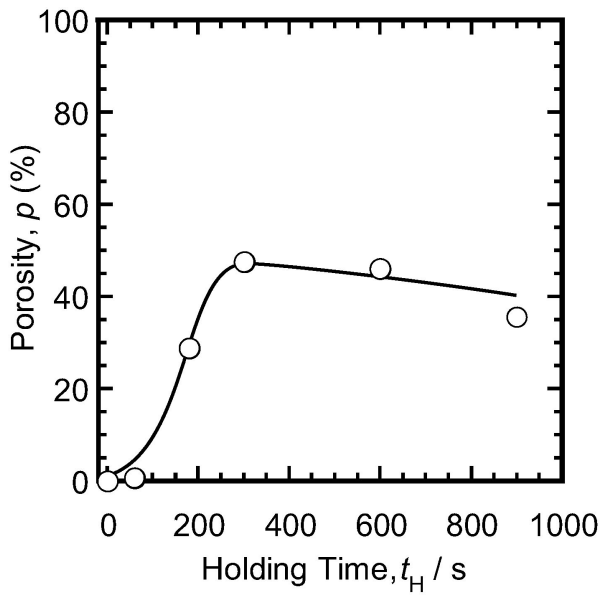

Fig. 5 Holding time dependency of the porosity for the specimen without the prestrain.

\section{2 加熱条件の効果}

予ひず反を与えなかった試験片に対し，加熱保持時間を 0 $\sim 900 \mathrm{~s}$ の間で変化させて発泡試験を行った．発泡試験中の 試験片温度プロファイルを Fig. 4 に示す. 試験片温度は, 約 $90 \mathrm{~s}$ で固相線温度 $\left(T_{\mathrm{S}} \approx 860 \mathrm{~K}\right)$ に達し, 約 $200 \mathrm{~s}$ で液相線 温度 $\left(T_{\mathrm{L}} \approx 915 \mathrm{~K}\right)$ に達した. 最終的に, 約 $600 \mathrm{~s}$ 後に約 $1020 \mathrm{~K}$ で飽和した。

気孔率を加熱保持時間の関数として Fig. 5 に示す. 固相 線温度以下では, 気孔率の増加はほとんど見られなかった。 半溶融領域で気孔率は急激に増加した。最大気孔率 $48 \%$ は 加熱保持時間 $300 \mathrm{~s}$ で観測された。 その後, 気孔率は加熱保 持時間の増加にともない減少した。

発泡後の試験片 $\left(t_{\mathrm{H}}=60,180,300,900 \mathrm{~s}\right)$ を $z$ 軸方向から観 察した結果を Fig. $6(\mathrm{a}) \sim(\mathrm{d})$ に示す. 全ての試験片は $x$ 軸方 向に伸張した異方的な形状を有していた， $t_{\mathrm{H}} \leq 180 \mathrm{~s} て ゙ は ， y$ 軸方向にほとんど膨張しなかったが， $t_{\mathrm{H}} \geq 300 \mathrm{~s}$ では， $y$ 軸 方向にも膨張した，発泡初期段階に扔いて，予ひず反を与え ない場合でも膨張は異方的であり, ホットプレス方向に優先 的に生じることが確認された。 

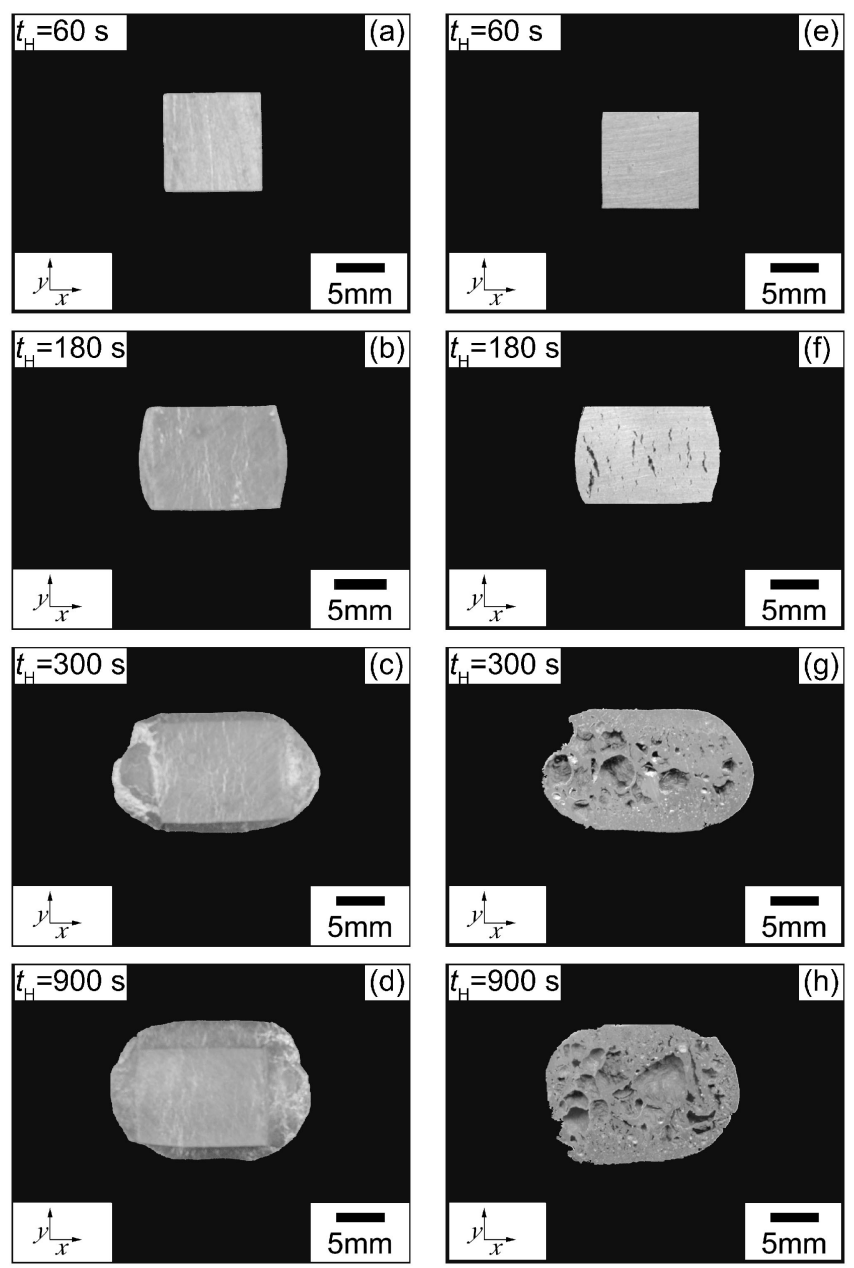

Fig. 6 Photographs of aluminum foams for different holding times (a) $t_{\mathrm{H}}=60 \mathrm{~s}$, (b) $t_{\mathrm{H}}=180 \mathrm{~s}$, (c) $t_{\mathrm{H}}=300 \mathrm{~s}$ and (d) $t_{\mathrm{H}}=$ $900 \mathrm{~s}$, and the cell morphology of aluminum foams for different holding times (e) $t_{\mathrm{H}}=60 \mathrm{~s},(\mathrm{f}) t_{\mathrm{H}}=180 \mathrm{~s},(\mathrm{~g}) t_{\mathrm{H}}=300 \mathrm{~s}$ and $(\mathrm{h})$ $t_{\mathrm{H}}=900 \mathrm{~s}$.

膨張方向異方性を定量的に示すために，試験片の偏差ひず 久を加熱保持時間の関数として Fig. 7 に示す. $\varepsilon_{x}^{\prime}$ は加熱保 持時間の増加にともない増加し， $t_{\mathrm{H}}=300 \mathrm{~s}$ で最大となり， その後減少した。一方， $\varepsilon_{y}^{\prime}$ は加熱保持時間の増加にともな い減少し, $t_{\mathrm{H}}=300 \mathrm{~s}$ で最小となり, その後増加した。 また, $\varepsilon_{z}^{\prime}$ は $t_{\mathrm{H}}=300 \mathrm{~s}$ までは， $\varepsilon_{y}^{\prime}$ と同様の傾向を示したが，その後 も減少し続けた. $x, y$ 軸は共に重力に対して重直であるので, $\varepsilon_{x}^{\prime}, \varepsilon_{y}^{\prime}$ の差はプリカーサの異方性の影響によるものである. 一方， $y, z$ 軸はホットプレス方向と垂直であるので， $\varepsilon_{y}^{\prime}, \varepsilon_{z}^{\prime}$ の差は発泡過程の重力の影響と考えられる。つまり, 発泡初 期に抢ける膨張方向異方性はプリカーサの異方性に依存し， 加熱保持時間の増加にともない重力の影響が相対的に強くな ることが定量的に確認された.

加熱保持時間ごとに試験片の $x-y$ 断面を観察した結果を Fig. 6 (e) 〜 (h) に示す. $x, y$ 軸に平行な断面では重力の影響 に差がないため，プリカーサの異方性と気孔形状の異方性の 関係を議論することができる， $t_{\mathrm{H}}=60 \mathrm{~s}$ の断面観察結果か ら，気孔はほとんど確認できなかった． $t_{\mathrm{H}}=180 \mathrm{~s}$ では気孔 径が小さく, 気孔形状は $x$ 軸に平行方向に扁平していた。 $t_{\mathrm{H}}$ $\geq 300 \mathrm{~s}$ では, 気孔径が大きくなった。 また，気孔径と気孔

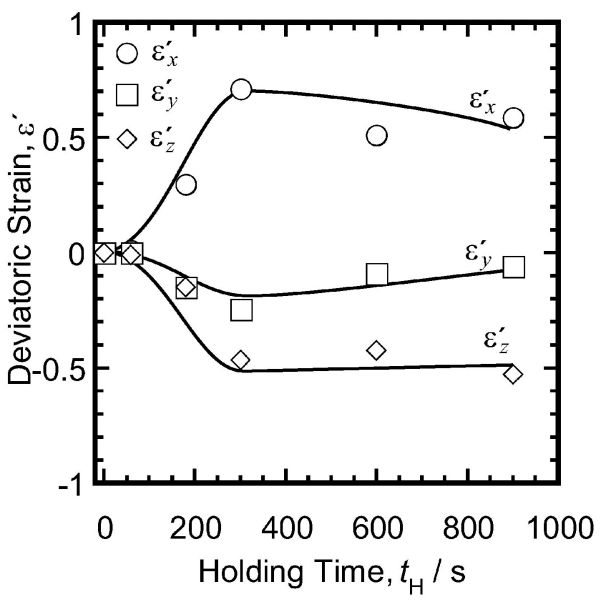

Fig. 7 Quantitative evaluation of the holding time dependency of the anisotropic expansion using the diagonal components of the deviatoric strain tensor.

形状のばらつきが確認された，気孔径と気孔形状について定 量的に議論するために, 平均気孔径 $d_{\mathrm{m}}$, 平均気孔アスペク ト比 $\alpha$ を加熱保持時間の関数として Fig. 8(a)にプロットし た. 平均気孔径は加熱保持時間の増加にともない増加した。 $t_{\mathrm{H}}=300 \mathrm{~s}$ に抢いて $d_{\mathrm{m}} \approx 0.8 \mathrm{~mm}$ となった後減少した. 平均 気孔径が気孔率と同様の傾向を示すことが確認された。平均 気孔アスペクト比は $t_{\mathrm{H}}=300 \mathrm{~s}$ まで増加し， $\alpha \approx 0.6$ で一定と なった. Fig. 6 に対応する試験片(但し， $t_{\mathrm{H}}=60 \mathrm{~s}$ は除く)の 気孔配向頻度分布をそれぞれ Fig. $8(\mathrm{~b}) \sim(\mathrm{d})$ に示す. $t_{\mathrm{H}}=$ $180 \mathrm{~s}$ に扔いて, $\theta=90^{\circ}$ 近傍の頻度が高いが，加熱保持時間

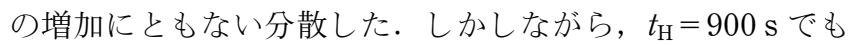
$\theta=90^{\circ}$ 近傍の頻度はわずかに高い。これらの結果は, 加熱保 持時間が $t_{\mathrm{H}} \leq 900 \mathrm{~s}$ の範囲では気孔形状が $x$ 軸方向に扁平し た異方的形状であることを示している。これまでに，押出し を用いて作製された 6061 アルミニウム合金プリカーサを約 $920 \mathrm{~K}$ で加熱保持した場合でも膨張方向の異方性は確認され ている11)。しかしながら, この報告では, 約 $350 \mathrm{~s}$ 保持後, 画像解析によって求めた気孔形状は円に近づくことが定量的 に調べられている．気孔形状に関する過去の報告との差異は マトリックス材料の違いによる粘度や表面張力の影響である と考えられる.

\section{3 予ひずみの効果}

予ひずみ $\varepsilon_{/ /}^{\mathrm{PS}}, \varepsilon_{\perp}^{\mathrm{PS}}$ を与えた試験片に対し，加熱保持時間 $t_{\mathrm{H}}$ $=300 \mathrm{~s}$ の発泡試験を行ったときの気孔率を予ひず $\left|\varepsilon_{|/|}^{\mathrm{PS}}\right|$, $\left|\varepsilon_{\perp}^{\mathrm{PS}}\right|$ の関数として Fig. 9 に示す. 気孔率は $\left|\varepsilon_{/ /}^{\mathrm{PS}}\right|=0.1$, $\left|\varepsilon_{\perp}^{\mathrm{PS}}\right|=0.14$ まで予ひずみの増加にともない増加した。 $\left|\varepsilon_{/ /}^{\mathrm{PS}}\right|,\left|\varepsilon_{\perp}^{\mathrm{PS}}\right|$ を与えた試験片の最大気孔率はそれぞれ，65， 61\%であった。これは，圧縮変形によりプリカーサ中の欠 陥が減少し, 水素ガスが試験片外部に放出されにくくなり, 気孔形成に有効に寄与したためと考えられる。最大気孔率に 達した後, 予ひずみの増加にともない気孔率は低下した。こ れは，プリカーサ中に生じたクラックより（Fig. 3 (b)， (c))，水素ガスが抜け出たためと考えられる.

発泡試験後の試験片の写真を Fig. 10 に示す。予ひずみ 

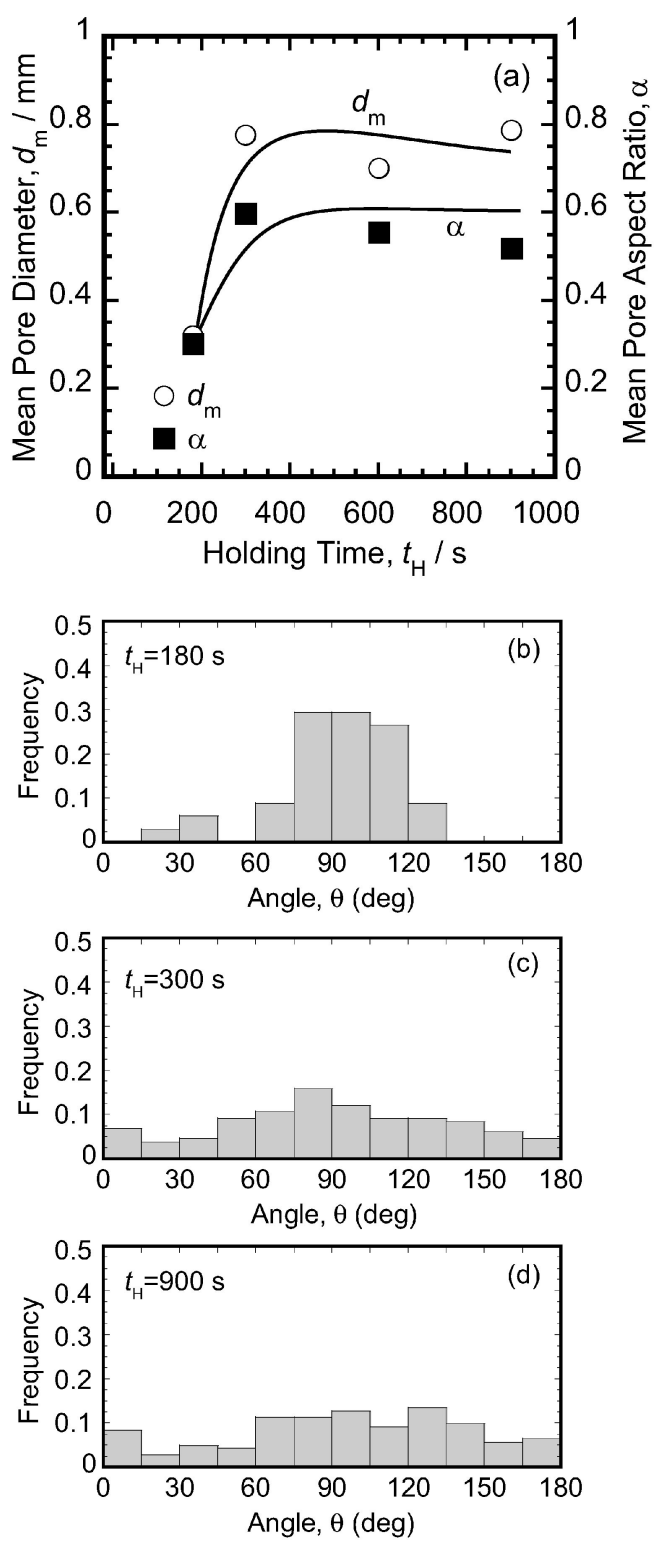

Fig. 8 Holding time dependency of the mean pore diameter $d_{\mathrm{m}}$ and the mean pore aspect ratio $\alpha$ (a). The distribution of the frequencies of the pore orientation at different holding times (b) $t_{\mathrm{H}}=180 \mathrm{~s},(\mathrm{c}) t_{\mathrm{H}}=300 \mathrm{~s}$ and $(\mathrm{d}) t_{\mathrm{H}}=900 \mathrm{~s}$.

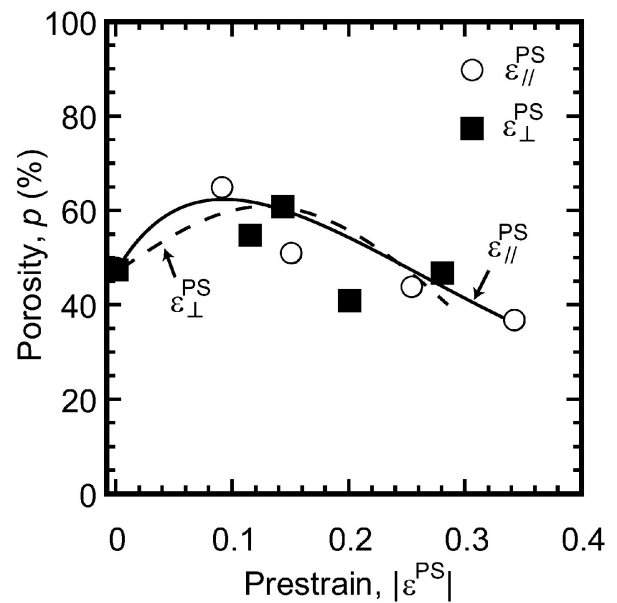

Fig. 9 Influence of the prestrain on the porosity. Comparison between the prestrains $\left|\varepsilon_{/ /}^{\mathrm{PS}}\right|$ and $\left|\varepsilon_{\perp}^{\mathrm{PS}}\right|$.
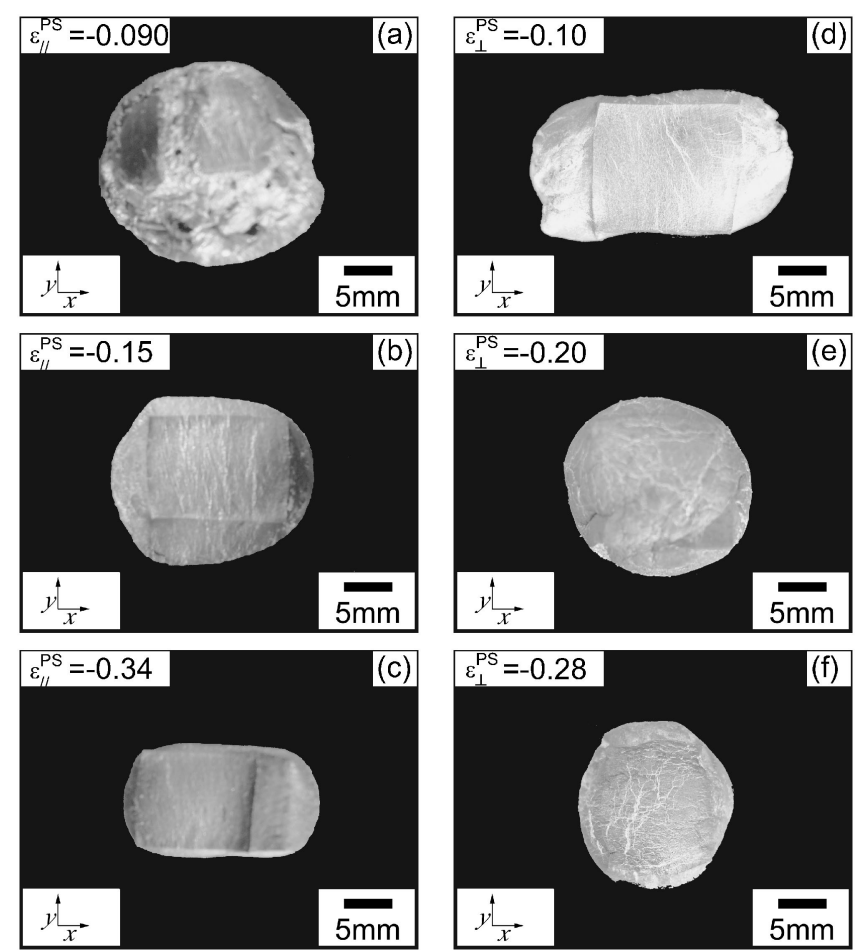

Fig. 10 Photographs of aluminum foams with different prestrains (a) $\varepsilon^{\mathrm{PS}}=-0.090$, (b) $\varepsilon^{\mathrm{PS}}=-0.15$, (c) $\varepsilon^{\mathrm{PS}}=-0.34$, (d) $\varepsilon_{\perp}^{\mathrm{PS}}=-0.10$, (e) $\varepsilon_{\perp}^{\mathrm{PS}}=-0.20$ and (f) $\varepsilon_{\perp}^{\mathrm{PS}}=-0.28$.

$\left|\varepsilon_{||}^{\mathrm{PS}}\right|,\left|\varepsilon_{\perp}^{\mathrm{PS}}\right|$ の増加にともなう優先膨張方向の変化が確認で きる． $\varepsilon_{/ /}^{\mathrm{PS}}$ を元た場合， $\left|\varepsilon_{/ /}^{\mathrm{PS}}\right|$ の増加にともない $x$ 軸と平行 方向に優先膨張方向が遷移した。一方， $\varepsilon^{\mathrm{PS}}$ を与えた場合， $\left|\varepsilon_{\perp}^{\mathrm{PS}}\right|$ の増加にともない $y$ 軸と平行方向に優先膨張方向が遷 移した．このような膨張方向異方性の变化を定量的に表すた めに， $\varepsilon_{/ /}^{\mathrm{PS}}, \varepsilon_{\perp}^{\mathrm{PS}}$ を与えた試験片の偏差ひず反を予ひずみの関 数として，それぞれ Fig. 11(a)，(b)に示した。 $\varepsilon_{\| /}^{\mathrm{PS}}$ をえた 場合, $\varepsilon_{x}^{\prime}$ が増加し， $\varepsilon_{y}^{\prime} か ゙$ 減少した。一方， $\varepsilon_{\perp}^{\mathrm{PS}}$ を与えた場合， $\varepsilon_{x}^{\prime}$ が減少し， $\varepsilon_{y}^{\prime}$ が増加した。このように予ひずみの方向に より優先膨張方向が変化することが定量的に確認された。

異なる予ひずみを与えた試験片の $x-y$ 断面を観察した結果 (Fig. 10 に対応する試験片)を Fig. 12 に示す． $\varepsilon_{/ /}^{\mathrm{PS}}$ をえた 場合, 気孔は $x$ 軸に平行に扁平した。また, $\left|\varepsilon_{/ /}^{\mathrm{PS}}\right|$ の増加に ともない周辺部の気孔が中央部と比較して少なくなった。一 方， $\varepsilon_{\perp}^{\mathrm{PS}}$ をえた場合，気孔は $y$ 軸に平行に扁平した。 $\left|\varepsilon_{\perp}^{\mathrm{PS}}\right|$ を与えたことによる気孔分布の偏りは確認されなかった。断 面観察結果上り, 平均気孔径 $d_{\mathrm{m}}$, 平均気孔アスペクト比 $\alpha$ をそれぞれ測定し，Fig. 13 (a)，Fig. 14（a）にプロットし た。平均気孔径はどちらも気孔率と同様の挙動を示し, 平均 気孔アスペクト比はどちらも $\alpha \approx 0.6$ であり，予ひずみが増 加しても変化しなかった． $\varepsilon_{\| / /}^{\mathrm{PS}}, \varepsilon_{\perp}^{\mathrm{PS}}$ を与えた場合の気孔配向 頻度分布をそれぞれ Fig. 13(b)〜 (d) , Fig. 14(b)〜 (d) に示 す. $\left|\varepsilon_{\| /}^{\mathrm{PS}}\right|$ の増加にともない $\theta=90^{\circ}$ 近傍の頻度が増加し, $\left|\varepsilon_{\perp}^{\mathrm{PS}}\right|$ の増加にともない $\theta=0,180^{\circ}$ 近傍の頻度が増加した。 これは， $\varepsilon^{\mathrm{PS}}$ を与えた場合，気孔の長軸方向が $x$ 軸に近づき， $\varepsilon_{\perp}^{\mathrm{PS}}$ を与えた場合, 気孔の長軸方向が $y$ 軸に近づくことを示 している。つまり，気孔の長軸方向は予ひずみを与えた方向 に配向する．プリカーサに与えた予ひずみは気孔形状とその 

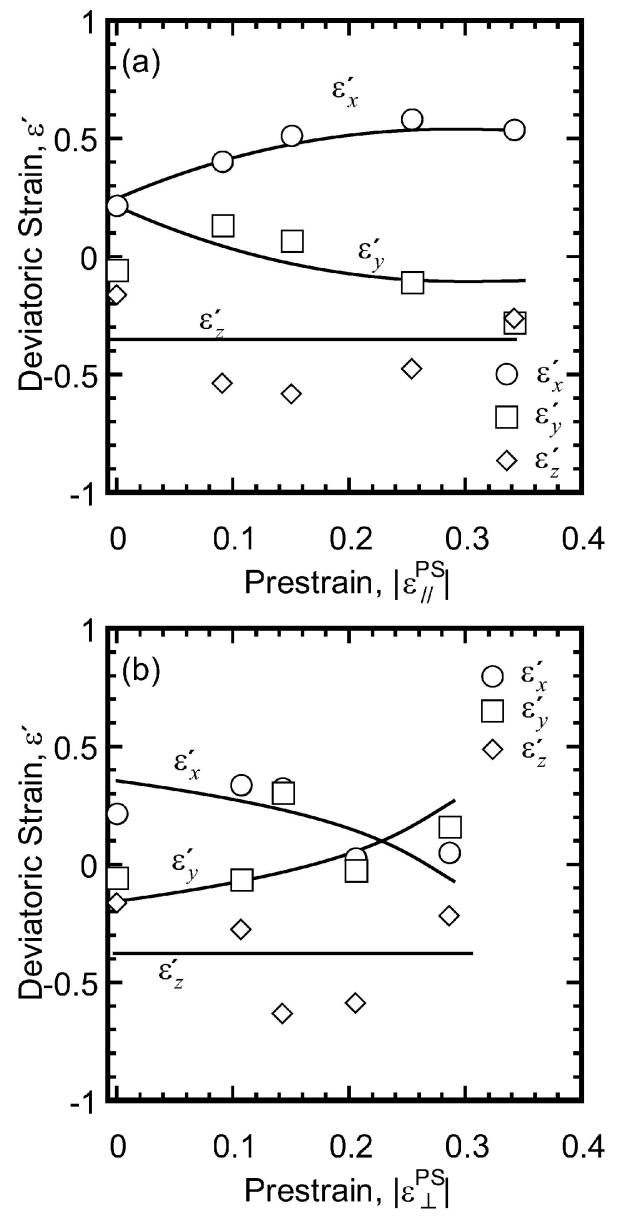

Fig. 11 Quantitative evaluation for influence of the prestrains (a) $\left|\varepsilon_{/ \|}^{\mathrm{PS}}\right|$ and (b) $\left|\varepsilon_{\perp}^{\mathrm{PS}}\right|$ on anisotropic expansion using the diagonal components of the deviatoric strain tensor.
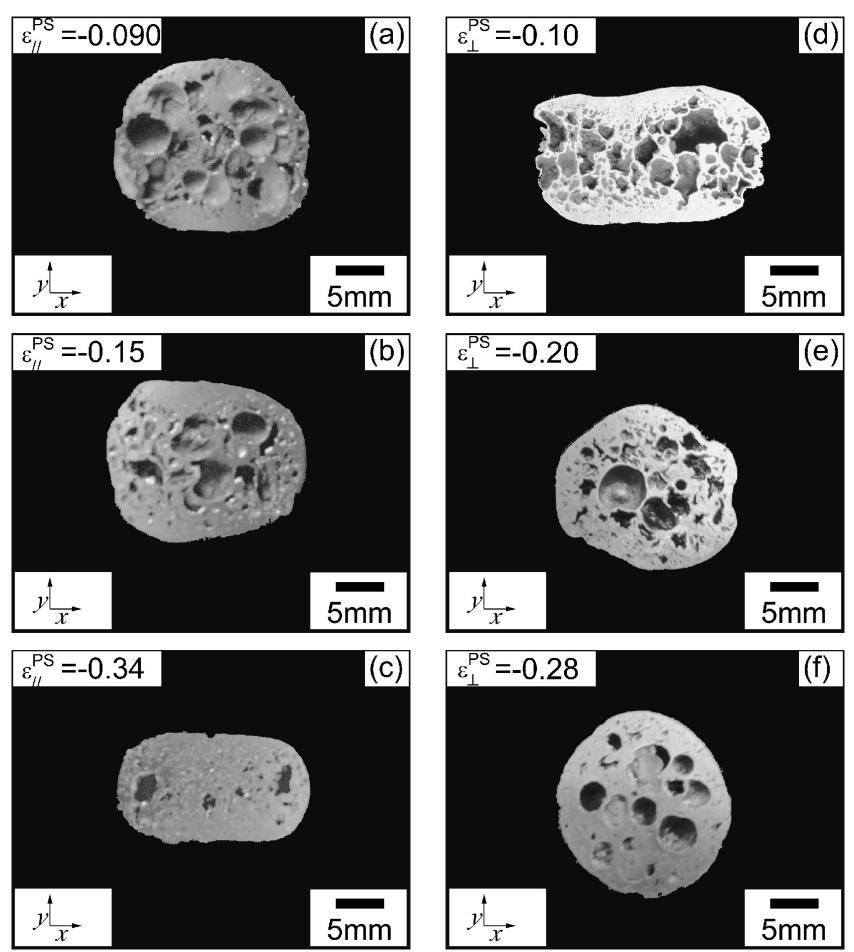

Fig. 12 Photographs of the cell morphology of the aluminum foams with different prestrains (a) $\varepsilon^{\mathrm{PS}}=-0.090$, (b) $\varepsilon^{\mathrm{PS}}=$ -0.15 , (c) $\varepsilon^{\mathrm{PS}}=-0.34$, (d) $\varepsilon_{\perp}^{\mathrm{PS}}=-0.10$, (e) $\varepsilon_{\perp}^{\mathrm{PS}}=-0.20$ and (f) $\varepsilon_{\perp}^{\mathrm{PS}}=-0.28$
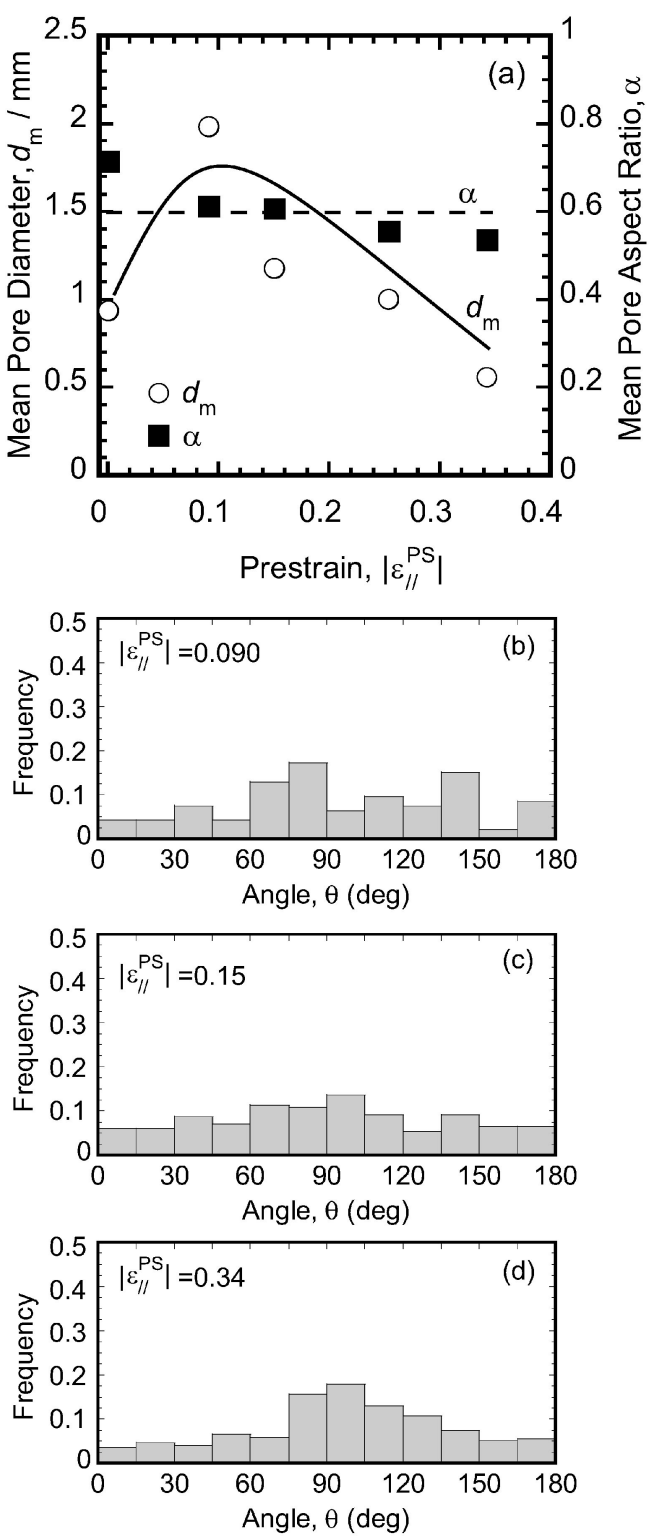

Fig. 13 Influence of the prestrain $\left|\varepsilon_{/ /}^{\mathrm{PS}}\right|$ on the mean pore diameter $d_{\mathrm{m}}$ and the mean pore aspect ratio $\alpha(\mathrm{a})$. The distribution of the frequencies of the pore orientation for different prestrains (b) $\left|\varepsilon_{/ /}^{\mathrm{PS}}\right|=0.090$, (c) $\left|\varepsilon_{/ /}^{\mathrm{PS}}\right|=0.15$ and (d) $\left|\varepsilon_{/ /}^{\mathrm{PS}}\right|=0.34$.

配向にも影響することが定量的に確認された．

4. 結 論

アルミニウムプリカーサの発泡挙動異方性における予ひず みの効果を定量的に評価した。

一軸ホットプレスを用いて作製された 5083 アルミニウム 合金プリカーサの膨張方向異方性を, 偏差ひずみを用いて定 量的に評価した. その結果, 加熱保持時間が短い場合, 発泡 挙動異方性に対し, 予ひずみの影響が大きくなることが確認 された。

プリカーサに室温で予ひずみを与えた場合, 予ひずみの増 加にともない，予ひずみ方向に対応する偏差ひずみの成分が 増加した. 圧縮ひずみを与えることで, 優先膨張方向が圧縮 方向に变化することが確認された. 発泡試験の重力方向に垂 

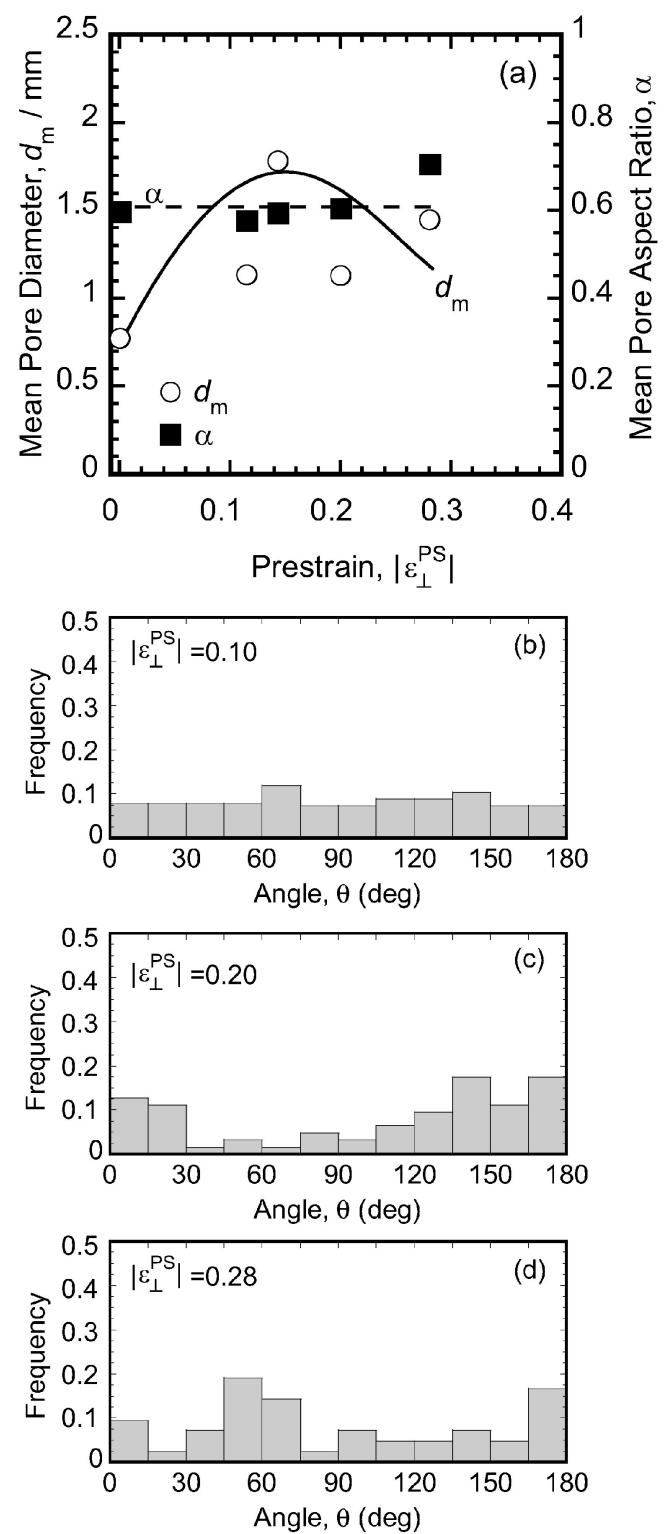

Fig. 14 Influence of the prestrain $\left|\varepsilon_{\perp}^{\mathrm{PS}}\right|$ on the mean pore diameter $d_{\mathrm{m}}$ and the mean pore aspect ratio $\alpha$ (a). The distribution of the frequencies of the pore orientation for different prestrains (b) $\left|\varepsilon_{\perp}^{\mathrm{PS}}\right|=0.10$, (c) $\left|\varepsilon_{\perp}^{\mathrm{PS}}\right|=0.20$ and (d) $\left|\varepsilon_{\perp}^{\mathrm{PS}}\right|=0.28$.
直な断面の気孔形状を平均気孔アスペクト比を用いて評価し た結果，気孔形状は圧縮ひずみの増加にともない，圧縮方向 に扁平する傾向が観察された.

以上のようにプリカーサ法において, 予ひずみは発泡過程 に重要な役割を果たすことが明らかとなった。言い換える と, 予ひずみを適切に制御できれば, near net-shape の発 泡構造体を効率よく作製できるだろう.

本研究の一部は, アルミニウム研究助成によって行われた ものであり，社団法人日本アルミニウム協会に謝意を表する.

文献

1) T. J. Lu, A. Hess and M. F. Ashby: J. Appl. Phys. 85(1999) $7528-7539$

2) K. Kitazono: Mater. Trans. 9(2006) 2223-2228.

3) J. Banhart: Prog. Mater. Sci. 46 (2001) 559-632.

4) N. Haydn and G. Wadely: Adv. Eng. Mater. 4(2002) 726-732.

5) N. Kanetake, M. Kobashi and S. Tsuda: Adv. Eng. Mater. 10 (2008) 840-844.

6) I. Duarte and J. Banhart: Acta Mater. 48(2000) 2349-2362.

7) C. Körner, F. Berger, M. Arnold, C. Stabelmann and R. Singer: Mater. Sci. Tech. 16(2000) 781-784.

8) A. Kennedy: Scr. Mater. 47 (2002) 763-767.

9) C. Körner, M. Arnold and R. Singer: Mater. Sci. Eng. A 396 (2005) 28-40.

10) F. Baumgärtner, I. Duarte and J. Banhart: Adv. Eng. Mater. 2 (2000) $168-174$.

11) M. Kobashi, N. Sakamoto and N. Kanetake: J. JILM 59(2009) $7-12$.

12) M. Kobashi, S. Tanahashi and N. Kanetake: J. JILM 53(2003) 427-432.

13) K. Kitazono, Y. Kikuchi, E. Sato and K. Kuribayashi: Mater. Lett. 61(2007) 1771-1774.

14) J. Banhart and J. Baumeister: J. Mater. Sci. 33(1998) 14311440.

15) K. Kitazono, E. Sato and K. Kuribayashi: Acta Mater. 51 (2003) $4823-4836$.

16) R. Suzuki and K. Kitazono: J. Japan Inst. Metals 72 (2008) 758762 . 